\title{
The destruction of vitamin A by blood*
}

\author{
By C. J. POLLARD AND J. G. BIERI \\ Laboratory of Nutrition and Endocrinology, National Institute of Arthritis and Metabolic \\ Diseases, Public Health Service, U.S. Department of Health, Education, \\ and Welfare, Bethesda, Maryland
}

(Received 28 February 1958)

In recent studies of the metabolism of vitamin $A$ and carotene the technique of intravenously injecting aqueous dispersions of these substances has frequently been used (Bieri \& Pollard, I954; Kon, McGillivray \& Thompson, I955; McGillivray, Thompson $\&$ Worker, 1956; Worker, 1956, 1957). The interesting observation was made by Kon et al. (1955) that when vitamin A alcohol was given intravenously to rats and rabbits the vitamin quickly disappeared from the circulation. Only one-fourth of the dose was found in the livers of rats after $15 \mathrm{~min}$. In studying this aspect of vitamin A metabolism in more detail, we have determined the distribution in the body of injected vitamin $A$ and also its rate of destruction by various organs. It has been found that vitamin $A$ is destroyed faster when incubated with the blood of young rats than with that of old rats. The destruction is associated with the red blood cells.

\section{EXPERIMENTAL AND RESULTS}

\section{Preparation of vitamin $A$ dispersions}

Crystalline vitamin A acetate (Distillation Products Industries, Rochester, N.Y.) was dissolved in warm $95 \%$ ethanol, Tween 40 (polyoxyethylenesorbitan monopalmitate, Atlas Powder Co., Wilmington, Delaware) added, and the solution diluted with $0.9 \%$ saline to give final concentrations of $12.5 \%$ ethanol and $5 \%$ Tween.

\section{Animals and diets}

Rats used for injection of vitamin A were males obtained from the Holtzman Company (Madison). They were maintained on a purified vitamin A-free diet (Bieri \& Sandman, I95 I) and used for experiment when the first signs of vitamin A deficiency were manifested (body-weight, IOO-I $5 \circ \mathrm{g}$ ). Rats used in the blood studies were of the Holtzman strain, but were obtained from the stock colony of the National Institutes of Health. They were maintained on commercial pellets. Mice and rabbits also were from the stock colony. Chicks and guinea-pigs were from experimental groups fed on various complete purified diets.

The solutions of vitamin A acetate were administered to rats orally by stomach tube or intravenously through the tail vein while the animal was under light ether anaesthesia. Blood was collected from rats and mice by decapitation or heart puncture; heart puncture was used for guinea-pigs, rabbits, and chicks.

* Read in part before the American Institute of Nutrition (Pollard \& Bieri, 1957). 


\section{Analytical methods}

Vitamin A analyses were done on the non-saponifiable extracts of all tissues, with the usual Carr-Price reagent. The carotene content of all extracts, except those from chick blood, was negligible. Analysis of whole animals was effected by chopping up the frozen carcass and then comminuting in a blender with alcoholic I I N-KOH $(0.5 \mathrm{ml}$./g tissue) before refluxing. Pyrogallol was added as an anti-oxidant. The entire saponification mixture was extracted with $n$-hexane. Reticulocyte counts were made by the method of Brecher \& Schneiderman (1950) with New Methylene Blue.

\section{Incubation of tissues with vitamin $A$}

Tissues were homogenized in $0.9 \%$ saline. Haemolysates of whole blood or red cells were prepared by freezing and thawing three times, with use of a dry ice-ethanol mixture. The homogenates or haemolysates were pipetted into $50 \mathrm{ml}$. glass-stoppered Erlenmeyer flasks containing $0.2-0.5 \mathrm{ml}$. of a solution of vitamin A in Tween, and incubated at $37^{\circ}$ for varying periods. The reaction was stopped by the addition of alcoholic $\mathrm{KOH}$, the mixture was then saponified and extracted with hexane.

\section{Distribution and rate of destruction of injected vitamin $A$}

To ascertain whether quantitative recovery of vitamin $A$ in determinations on whole animals was being obtained, $233 \mu \mathrm{g}$ of vitamin A in Tween were placed in a blender containing an homogenate in alcoholic $\mathrm{KOH}$ of a rat severely deficient in vitamin $\mathrm{A}$. Analysis of whole depleted rats had revealed only $2-4 \mu \mathrm{g}$ of vitamin A. The homogenate was remixed and taken through the analytical procedure. The vitamin was recovered to the extent of $95 \%$.

That vitamin A is rapidly destroyed after intravenous injection is shown by the following experiment. Vitamin A acetate ( $130 \mu \mathrm{g}$ in $0.2 \mathrm{ml}$. solution) was injected intravenously into two vitamin A-deficient rats (body-weight, $120-130 \mathrm{~g}$ ) under light ether anaesthesia. The animals were immediately killed with ether, cut into small pieces with scissors, homogenized in alcoholic $\mathrm{KOH}$ and taken through the analytical procedure just described. Less than 5 min elapsed between the injection and the homogenization. Of the injected vitamin 64 and $44 \%$, respectively, was recovered.

In order to get some insight into the course taken by the injected vitamin, analyses were made at intervals of those tissues where vitamin $\mathrm{A}$ is known to accumulate. Vitamin A acetate was injected intravenously into deficient rats weighing $100-120 \mathrm{~g}$. Two series of experiments were carried out and the results are shown in Table $\mathbf{r}$.

In the whole animal (Table I, Exp. 2, last column) only about $44 \%$ of the dose remained after $2 \mathrm{~h}$, most of the loss undoubtedly occurring in the first few minutes, as shown above. The vitamin $\mathrm{A}$ in the blood serum fell quite rapidly until a normal concentration was reached in about $8 \mathrm{~h}$. Little of the vitamin appeared in the lungs or kidneys and adrenal glands at any time. Of particular interest is the initial large amount in the liver after $5 \mathrm{~min}$, the rapid decrease to a constant level during the $2-4 \mathrm{~h}$ period, followed by a doubling of the vitamin A by $8 \mathrm{~h}$. It would appear that more than half of the vitamin was distributed throughout the body, perhaps in the muscle 
mass, during the first $4 \mathrm{~h}$, but by $8 \mathrm{~h}$ the liver had picked up all but about ro $\mu \mathrm{g}$ of that left undestroyed. The delay in storing the vitamin may represent time required for saturation of the tissues before storage in the liver.

Table I. Distribution of vitamin $A$ in depleted rats, weighing from 100 to $\mathrm{r} 20 \mathrm{~g}$ and aged 38 to 44 days, after intravenous injection of vitamin $A$ acetate in $0.2 \mathrm{ml}$. of a $5 \%$ solution of Tween 40

\begin{tabular}{|c|c|c|c|c|c|c|c|c|}
\hline \multirow[b]{2}{*}{$\begin{array}{c}\text { Exp. } \\
\text { no. }\end{array}$} & \multirow[b]{2}{*}{$\begin{array}{l}\text { No. of } \\
\text { rats }\end{array}$} & \multirow[b]{2}{*}{$\begin{array}{c}\text { Dose of } \\
\text { vitamin A } \\
(\mu \mathrm{g})\end{array}$} & \multirow[b]{2}{*}{$\begin{array}{l}\text { Time between } \\
\text { injection } \\
\text { and killing } \\
\text { (h) }\end{array}$} & \multicolumn{5}{|c|}{ Vitamin $A^{*}$} \\
\hline & & & & $\begin{array}{c}\text { Serum } \\
(\mu \mathrm{g} / \mathrm{r} 00 \mathrm{ml} .) \dagger\end{array}$ & $\begin{array}{l}\text { Liver } \\
(\mu \mathrm{g})\end{array}$ & $\begin{array}{l}\text { Lungs } \\
(\mu \mathrm{g})\end{array}$ & $\begin{array}{l}\text { Kidneys and } \\
\text { adrenal glands } \\
(\mu \mathrm{g})\end{array}$ & $\begin{array}{l}\text { Whole } \\
\text { animal } \\
(\mu \mathrm{g})\end{array}$ \\
\hline \multirow[t]{5}{*}{ I } & 2 & 92 & $-\frac{1}{12}$ & I 45 & $32 \cdot 8$ & $2 \cdot 8$ & $1 \cdot 7$ & - \\
\hline & 2 & 92 & 2 & 102 & $13.8 t$ & $I \cdot O$ & 3.8 & - \\
\hline & 2 & 92 & 4 & 76 & $16 \cdot 7$ & 0.8 & $2 \cdot 9$ & - \\
\hline & 2 & 92 & 8 & 44 & 30.5 & $\mathrm{I} \cdot 8$ & $2 \% 7$ & - \\
\hline & 2 & 92 & 24 & 45 & $33 \cdot 8$ & $2 \cdot 4$ & $2 \cdot 5$ & - \\
\hline \multirow[t]{3}{*}{2} & 3 & I 15 & 2 & 93 & 10.3 & 0.9 & $2 \cdot 9$ & $43.7 \hbar$ \\
\hline & 3 & II 5 & 8 & 37 & $34 \cdot 9$ & $I \cdot 4$ & $I \cdot 2$ & $34.6 t$ \\
\hline & 3 & II 5 & 24 & 26 & $37 \cdot 4$ & $I \cdot 9$ & I'O & 34.01 \\
\hline
\end{tabular}

* Values are means for the number of rats shown.

† The blood volume of a rat of this weight is about $7 \mathrm{ml}$. (Creskoff, Fitz-Hugh \& Farris, 1949).

$\ddagger$ Value represents one animal only.

\section{Destruction of vitamin $A$ by tissues in vitro}

Systematic search was next made by experiments in vitro to determine which tissues were responsible for the destructive action observed when vitamin A was injected intravenously. Preliminary experiments with vitamin A-depleted rats (40-60 days old) indicated that vitamin A was relatively stable when incubated with homogenates of liver, kidney, lung or spleen. The first clue as to the possible site of destruction came after the following experiments. Vitamin A $(100 \mu \mathrm{g})$ in Tween was incubated

Table 2. Destruction of vitamin $A$ in vitro by elements of the blood* from normal rats $30-40$ days old

\begin{tabular}{|c|c|c|}
\hline Exp. & System & $\begin{array}{c}\text { Vitamin A } \\
\text { destroyed } \\
(\%)\end{array}$ \\
\hline A & $\begin{array}{l}\text { Ioo } \mu \mathrm{g} \text { vitamin } A \text { acetate incubated for } 2 \mathrm{~h} \text { at } 37^{\circ} \text { with } \\
\text { Haemolysed whole blood, } 6 \mathrm{ml} \text {. }\end{array}$ & $4^{6}$ \\
\hline $\mathrm{B}$ & Haemolysed whole blood, $5 \mathrm{ml}$ & 34 \\
\hline C & Washed red blood cells (haemolysed), $5 \mathrm{ml}$. & 86 \\
\hline $\mathrm{D}$ & Serum from blood cells in Exp. C, $4 \mathrm{ml}$. & 6 \\
\hline & Water, $5 \mathrm{ml}$. & 6 \\
\hline
\end{tabular}

for $2 \mathrm{~h}$ with haemolysed whole blood, with washed, haemolysed red blood cells, or with serum, all from normal young rats $30-40$ days old, or with water as a control. The results are shown in Table 2.

Non-haemolysed whole blood (results not shown) had slight activity; probably some haemolysis occurred when the Tween solution was added. It is evident that the 
destructive activity was associated with the red blood cells and that no activity resided in the serum.

Attempts were next made to use larger rats, not vitamin A-deficient, in order to get greater quantities of blood for studying the mechanism of the destruction. Varying degrees of success attended the experiments. Invariably, red blood cells from old rats failed to demonstrate high destructive activity when compared with cells obtained from young rats. Table 3 shows the effect of the age of the rats on the destruction of vitamin A by whole-blood haemolysates. It is apparent that the destructive system

\section{Table 3. Destruction of vitamin $A$ in vitro by pooled blood from normal, non-depleted rats of different ages}

( $1.5 \mathrm{ml}$. haemolysed whole blood, $3.0 \mathrm{ml}$. $0.9 \%$ saline and $220 \mu \mathrm{g}$ vitamin A acetate in $0.4 \mathrm{ml}$. of a $5 \%$ solution of Tween 40 ; incubated for $2 \mathrm{~h}$ at $37^{\circ}$ )

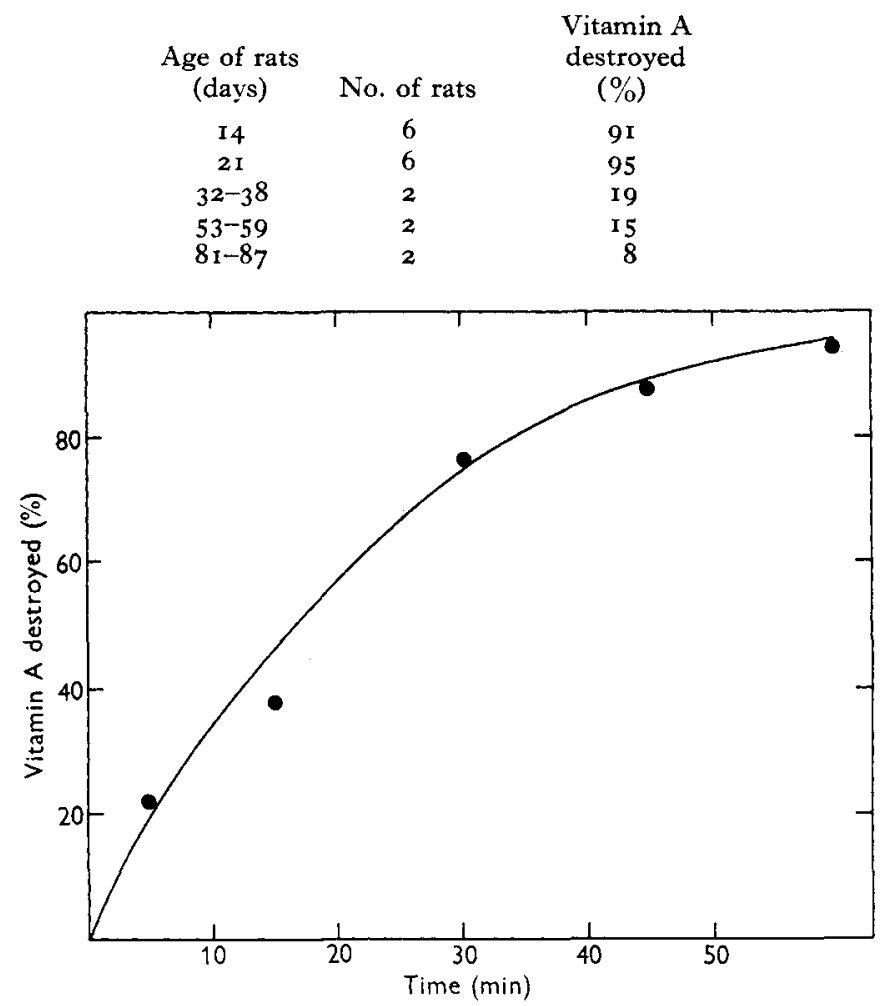

Fig. I. Rate of destruction of vitamin A acetate by haemolysed whole blood from $2 \mathrm{I}$-day-old rats. Each point represents the result from one flask containing $210 \mu \mathrm{g}$ vitamin $\mathrm{A}$ acetate in $0.4 \mathrm{ml}$. Tween 40 solution, $1.6 \mathrm{ml} .0 .9 \%$ saline and $1.0 \mathrm{ml}$. pooled haemolysed blood, incubated at $37^{\circ}$ for the time shown.

was very active in young rats, but that it decreased markedly after the $5^{\text {th }}$ week of life. In general, it has been found that under the conditions given in Table 3 the blood of rats 60 days of age or older will destroy about ro-20\% of the added vitamin $A$, whereas blood from rats less than $35-40$ days old will destroy from $70-80 \%$ (see also Table 5 ).

The time course of the destruction under the standardized conditions usually used is shown in Fig. I. Nearly one-half of the vitamin had disappeared after $15^{-20} \mathrm{~min}$, 
and after $\mathrm{I} h$ the destruction was essentially complete. The possibility was considered that blood from old rats may contain an inhibitor for the destruction. So blood from old rats, possessing little activity, was incubated with blood from young rats. No inhibition of the destruction occurred.

\section{Studies with reticulocytes}

The effect of age on the destruction of vitamin A by rat blood suggested that perhaps the presence of reticulocytes, known to be present in greater proportion in the blood of young animals, might be responsible for the observed phenomenon. To test the hypothesis a reticulocytosis was induced in stock rats, 70-80 days old (body-weight I90-2rog), by injecting phenylhydrazine (Wintrobe, r956). Neutralized phenylhydrazine hydrochloride, $40 \mathrm{mg} / \mathrm{kg}$ body-weight, was injected subcutaneously on 2 alternate days. At intervals whole blood was taken by heart puncture, haemolysed and tested for vitamin A-destructive activity. Table 4 gives the results for one rat. It can be seen that, whereas blood from a non-injected rat destroyed $20 \%$ of the

Table 4. Vitamin A-destructive activity in vitro of blood from a 70-day-old rat injected with phenylhydrazine

( $\mathrm{r} .0 \mathrm{ml}$. haemolysed whole blood, $0.6 \mathrm{ml} .0 .9 \%$ saline and $200 \mu \mathrm{g}$ vitamin A acetate in $0.4 \mathrm{ml}$. of a $5 \%$ solution of Tween 40 ; incubated for $\mathrm{I} h$ at $37^{\circ}$ )

\begin{tabular}{|c|c|c|c|}
\hline $\begin{array}{l}\text { Time after last } \\
\text { injection (days) }\end{array}$ & $\begin{array}{c}\text { Haematocrit } \\
(\%)\end{array}$ & $\begin{array}{c}\text { Reticulocytes } \\
(\%)\end{array}$ & $\begin{array}{c}\text { Vitamin A } \\
\text { destroyed } \\
(\%)\end{array}$ \\
\hline 4 & $19 \cdot 0$ & $\longrightarrow$ & $66 \cdot 5$ \\
\hline 8 & 17.5 & $44^{\circ} \circ$ & $82 \cdot 0$ \\
\hline I2 & $12 \cdot 3$ & $36 \cdot 5$ & 24.0 \\
\hline Control, not injected & $48 \cdot 0$ & $<\mathrm{I} \cdot 0$ & $20 \cdot 6$ \\
\hline
\end{tabular}

vitamin, the blood from the rat made anaemic with phenylhydrazine had considerably more destructive activity on the 4 th and 8 th days. By the 12 th day the activity had fallen to that of the non-injected rats. It is apparent that, although the high activity on the $4^{\text {th }}$ and 8 th days was accompanied by an increase in reticulocytes, there was no direct correlation between their number and the destructive system.

In order to get more information on this point, a group of $2 \mathrm{I}$-day-old male rats was placed on a commercial diet; at intervals they were killed and their blood tested. Haematocrit values and reticulocyte counts were determined. The results are shown in Table 5. The degree of destruction decreased as the reticulocyte count decreased, but it is apparent that the activity was not correlated directly with the number of reticulocytes. Although in counting reticulocytes all cells with stainable reticulum are counted, regardless of the degree of maturity of the cells, it is not probable that the lack of direct correlation was due to that variable in the technique of counting.

In a limited study it was found that the vitamin A-destructive activity increased in the blood of mature rats as a result of reticulocytosis produced by bleeding (results not shown here). The possibility that phenylhydrazine may have been involved in the destruction in the above studies can thus be ruled out. In addition to its presence in the blood, the destructive activity was found also in the spleen of 14 -day-old rats but not in the spleen of old rats, though it did occur in the spleen of old rats after reticulocytosis had been elicited by phenylhydrazine. 
Table 5. Relationship between age, reticulocyte count and destruction of vitamin $A$ by rat blood in vitro

$(0.5 \mathrm{ml}$. haemolysed whole blood, $1.0 \mathrm{ml} .0 .9 \%$ saline and $200 \mu \mathrm{g}$ vitamin A acetate in $0.5 \mathrm{ml}$. of a $5 \%$ solution of Tween 40 ; incubated for I h at $37^{\circ}$ )

$\begin{array}{cccc}\begin{array}{c}\text { Age of rat } \\ \text { (days) }\end{array} & \begin{array}{c}\text { Haematocrit } \\ (\%)\end{array} & \begin{array}{c}\text { Reticulocytes } \\ (\%)\end{array} & \begin{array}{c}\text { Vitamin A } \\ \text { destroyed } \\ (\%)\end{array} \\ 25^{*} & 34 \cdot 0 & 13 \cdot 2 & 74 \cdot 6 \\ 30 & 40 \cdot 0 & 16 \cdot 4 & 69 \cdot 0 \\ 30 & 41 \cdot 5 & 14 \cdot 1 & 71 \cdot 2 \\ 36 & 36 \cdot 0 & 10 \cdot 0 & 71 \cdot 5 \\ 36 & 38 \cdot 0 & 7 \cdot 4 & 61 \cdot 5 \\ 44 & 50 \cdot 0 & 5 \cdot 8 & 24 \cdot 0 \\ 44 & 40 \cdot 5 & 3 \cdot 7 & 22 \cdot 1 \\ 90 & 43 \cdot 0 & 1 \cdot 2 & 28 \cdot 1 \\ 90 & - & - & 23 \cdot 6\end{array}$

* Pooled blood of three rats; all other values for single rats.

\section{Species specificity}

Blood from animals of other species was compared with rat blood. As seen in Table 6, blood from I4-day-old rabbits had great activity which largely disappeared by the time the rabbits were 35 days old. Mouse blood had significant destructive action at $\mathrm{I} 4$ days old. The guinea-pig blood had considerably less activity. No appreciable activity could be demonstrated in chick blood even after phenylhydrazine injection.

Table 6. Destruction of vitamin $A$ in vitro by blood of young animals of different species

( $\mathrm{m} \mathrm{ml}$. haemolysed whole blood, $1.6 \mathrm{ml} .0 .9 \%$ saline and $230 \mu \mathrm{g}$ vitamin A acetate in $0.4 \mathrm{ml}$. of a $5 \%$ solution of Tween 40 ; incubated for $\mathrm{I} \mathrm{h}$ at $37^{\circ}$ )

$\begin{array}{lccc}\text { Species } & \begin{array}{c}\text { No. of } \\ \text { animals }\end{array} & \begin{array}{c}\text { Age } \\ \text { (days) }\end{array} & \begin{array}{c}\text { Vitamin A } \\ \text { destroyed* } \\ (\%)\end{array} \\ \text { Rat } & 3 & \text { I4 } & 44 \\ \text { Rat } & 3 & 2 \text { I } & 45 \\ \text { Mouse } & 5 & \text { I4 } & 20 \\ \text { Mouse } & 5 & 2 \text { I } & 4 \\ \text { Guinea-pig } & \text { I } & 8 & \text { I2 } \\ \text { Rabbit } & 2 & \text { I4 } & 77 \\ \text { Rabbit } & 2 & 35 & 4 \\ \text { Chick } & 4 & \text { I, 7, I4, 28 } & 0\end{array}$

* Blood from the number of animals shown was pooled, except for the rabbits (means for two animals) and the chicks (no activity at any range).

\section{Destruction of different forms of vitamin $A$, and of carotene}

It was considered of interest to determine the action of rat blood on various forms of vitamin A. As can be seen in Table 7, the acetate and free alcohol were destroyed to a similar extent. Anhydrovitamin A, prepared by the method of Shantz, Cawley \& Embree (1943), was the most easily destroyed. The palmitate ester and natural esters from fish oil were considerably more resistant. Thus, the long-chain fatty-acid esters were destroyed at a slower rate than the alcohol or the acetate. 
No extensive studies have been conducted with carotene, but several trials indicated that its rate of destruction in incubation in vitro with haemolysed whole blood was similar to that of vitamin A.

Table 7. Destruction of different forms of vitamin $A$ in vitro by blood of 21 -day-old rats $(0.5 \mathrm{ml}$. haemolysed whole blood, $\mathrm{r} .6 \mathrm{ml}$. $0.9 \%$ saline and $0.4 \mathrm{ml}$. of a $5 \%$ solution of Tween 40 containing the designated form of vitamin $A$; incubated for $1 \mathrm{~h}$ at $37^{\circ}$ )

\begin{tabular}{|c|c|c|}
\hline Form of vitamin $\mathrm{A}$ & $\begin{array}{c}\text { Vitamin } A, \\
\text { amount in system* } \\
(\mu \mathrm{g})\end{array}$ & $\begin{array}{l}\text { Vitamin A } \\
\text { destroyed } \\
(\%)\end{array}$ \\
\hline Acetate & I3I & 62 \\
\hline Acetate & 144 & 60 \\
\hline Acetate & 174 & 63 \\
\hline Acetate & 234 & 57 \\
\hline Alcohol & 179 & 66 \\
\hline Anhydro $†$ & 316 & 83 \\
\hline Palmitate & 137 & 28 \\
\hline Palmitate & 166 & 20 \\
\hline Palmitate & 179 & I9 \\
\hline Natural esters $f$ & r 38 & 36 \\
\hline
\end{tabular}

\section{DISCUSSION}

The studies presented indicate that a remarkable property of the haemolysed blood from young animals is its ability to destroy rapidly vitamin A and also carotene. Rabbit and rat blood were more active in this respect than the blood of mice, guinea-pigs and chicks. The activity resided in the red cells and was liberated on rupture of the cell. From the fact that high activity was found only in blood containing reticulocytes it would appear that they were the blood constituents most actively involved. The lack of a more positive correlation between number of reticulocytes and the destructive activity suggests that the system is complex; possibly activators or inhibitors may be involved.

A partial explanation of the destruction of vitamin A by blood may be found in the study by Rapoport, Gerischer-Mothes \& Nieradt (1955). They reported that blood from rabbits made anaemic by injecting phenylhydrazine contained increased amounts of unsaturated fatty acids and peroxides. The fatty acids underwent autoxidation which was accelerated by the presence of haemoglobin from haemolysed red cells. Although Rapoport et al. implicated the reticulocytes in the reaction, they could find no correlation between their number and the rate of oxygen consumption. The system was not inhibited by tocopherol, which would tend to rule out an autoxidation mechanism. The later work of this group (Rapoport \& Gerischer-Mothes, 1955; Hofmann, Rapoport \& Kesselring, 1956) and of Rubinstein, Ottolenghi \& Denstedt (1956) has shown that the reticulocyte contains numerous enzymes not possessed by the mature red cell. Consequently, the oxidative system first studied by Rapoport and his associates was a complex one, and its relation to the system reported here is difficult to ascertain. From preliminary experiments with blood from young rats we have 
found that distinct differences exist when comparison is made with the blood of anaemic rabbits used by Rapoport et al. (1955). Further work is being conducted along this line.

The significance of the destructive system in the normal animal remains to be determined. It is very possible that the normally slow destruction of vitamin $A$ in the body may occur primarily in the reticulo-endothelial system. If, conceivably, some systemic condition should cause an accelerated breakdown of the red cells with a resultant reticulocytosis, the loss of vitamin $A$ in the body could be accelerated. To the authors' knowledge, however, no reports exist that blood vitamin $A$ is lowered in such conditions as, for example, haemolytic anaemia.

\section{SUMMARY}

I. When vitamin A acetate dispersed in water with Tween 40 was injected intravenously into rats, one-third to one-half of the vitamin was destroyed within 5 min.

2. Incubation of vitamin $A$ with homogenates of certain rat tissues indicated that only haemolysed red blood cells would destroy significant amounts of the vitamin.

3. The destructive activity was high in blood of rats less than 40 days old and diminished rapidly in older rats. Experiments with rats made anaemic with phenylhydrazine or by bleeding suggested that the activity was associated with the reticulocytes, but no direct correlation could be found.

4. Blood of young rabbits showed a rate of destruction of vitamin A similar to that of the blood of young rats. Blood of young mice and guinea-pigs was less active, and chick blood was inactive.

5. The destruction of vitamin $A$ acetate and alcohol and of anhydro-vitamin A in vitro by rat blood was considerably faster than that of vitamin A palmitate or the natural esters from fish oils.

\section{REFERENCES}

Bieri, J. G. \& Pollard, C. J. (1954). Brit. F. Nutr. 8, 32.

Bieri, J. G. \& Sandman, R. P. (I95I). Proc. Soc. exp. Biol., N. Y., 77, 617.

Brecher, G. \& Schneiderman, M. (1950). Amer. F. clin. Path. 20, 1079.

Creskoff, A. J., Fitz-Hugh, T., Jr. \& Farris, E. J. (1949). In The Rat in Laboratory Investigation, 2nd ed., p. 406. [E. J. Harris and J. Q. Griffith, Jr., editors.] Philadelphia: J. B. Lippincott Co.

Hofmann, E. C. G., Rapoport, S. \& Kesselring, K. (1956). Hoppe-Seyl. Z. 304, 157.

Kon, S. K., McGillivray, W. A. \& Thompson, S. Y. (1955). Brit. F. Nutr. 9, 244.

McGillivray, W. A., Thompson, S. Y. \& Worker, N. A. (1956). Brit. F. Nutr. 10, 1 26.

Pollard, C. J. \& Bieri, J. G. (1957). Fed. Proc. 16, 396.

Rapoport, S. \& Gerischer-Mothes, W. (1955). Hoppe-Seyl. Z. 302, 167.

Rapoport, S., Gerischer-Mothes, W. \& Nieradt, C. (1955). Hoppe-Seyl. Z. 300, I74.

Rubinstein, D., Ottolenghi, P. \& Denstedt, O. F. (1956). Canad. F. Biochem. Physiol. 34, 222.

Shantz, E. M., Cawley, J. D. \& Embree, N. D. (1943). F. Amer. chem. Soc. 65, 901.

Wintrobe, M. W. (1956). Clinical Hematology, p. 808. Philadelphia: Lea and Febiger.

Worker, N. A. (1956). Brit. F. Nutr. ro, 169.

Worker, N. A. (1957). Brit. $\mathcal{F}$. Nutr. I1, 44 . 